\title{
Problems Arising from Discriminatory Treatment of Inmates of Nigerian Correctional Service
}

\author{
Jide OLORUNMOLA, Rasheed OKUNOLA, Eyitayo OYEYIPO*, Oluwakemisola OYEYIPO \\ Landmark University, Nigeria \\ *Corresponding Author
}

\begin{abstract}
In Penal Institutions Social discrimination often poses a stumbling block to reformation and rehabilitation of inmates. Several Studies exist on treatment of inmates, however only few studies have investigated disparate treatment among HighProfile and Low-Profile Inmates of Nigerian correctional services. This study, therefore, investigated discriminatory treatment among High-Profile and Low-Profile inmates in Lagos correctional Command and its implications for reformation and rehabilitation.
\end{abstract}

The research was based on Max Weber's theory of Life chances using descriptive research design .The research used a multistage sampling technique. Lagos Correctional Centres were purposively selected because they were noted for keeping all classes of inmates. Taro Yamane formula was used to randomly select 299 general duty Staff and inmates across three Correctional Centres in Kirikiri and Ikoyi axes. Sixteen (16) Key Informant interviews were conducted for Staff while 51 In-depth interviews were done which included 42 Inmates and nine trained guards with experience in handling all Classes of Inmates.

A larger percentage of the High-Profile Inmates were satisfied with the treatment meted out to those in custody while a larger percentage of the Low-Profile Inmates were not satisfied with their treatment

The study arrived at the conclusion that discriminatory treatment of Inmates creates difficulty in control of Inmates and hampers the cardinal objective of the Correctional Service which is reformation and rehabilitation of Inmates.

Key Words: Correctional Service/Centres, Discriminatory Treatments, Inmates, Nigeria

\section{PREAMBLE}

Globally, social discrimination is a common Hedwig, Kristian and Megan, 2012). In Penal Institutions, there are different classes of Inmates thus: Males/Females, awaiting trial persons/convicted, Muslims/Christians, and others. Sometimes, Lunatics, different races, and generally, Low-Class and High-Class Inmates who bring into Correctional Centres their varying life experiences (Clarke, 2010, Schaefer, 2012, Nicola, 2017, FIDH, 2017, Olorunmola, 2018). The ability of Correctional Officials to manage effectively the affairs /treatment of Inmates and the challenges that may arise there-from are very essential for reformation, rehabilitation and ultimately, reintegration. Correctional Officials are trained to treat all Inmates equally and justly in accordance with extant rules especially the United Nations Minimum Standard rules for treatment of offenders otherwise known as Mandella Rules (Uju and Ogun, 2000). However, in the course of treatment of the different categories of Inmates afore-mentioned, using equal parameter is almost a mirage. What are commonly obtainable are differential treatments almost like a caste system (Schmallenger, 1974; Okunola, Aderinto and Atere, 2000, Aborisade 2019). Thus, social discrimination with its attendant implications for social justice is hardly avoidable .Consequently, this hampers reformation, rehabilitation and reintegration of Inmates back to the main society (Aminu and Ab Halim, 2015) and often times leads to riots

\subsection{The Problem}

The correctional centre no doubt house inmates of different classes such as the low-class and the high-class inmates. The social status of inmates determines the categorization of such inmates within the four walls of the correctional centre. The difference in status has generated different kinds of problems between the low-class inmates, the high-class inmates as well as the correctional staff. Correctional Staff usually feel ambivalent regarding how to maintain a balance between the privileges of the high profile and low profile Inmates (Madaki, 2011, Aborisade, 2019). The differentia treatment of inmates often engenders different feelings and reactions amongst the inmates. Low-Class Inmates feel psychologically humiliated, oppressed, and alienated by the privileges given to their high-Profile colleagues, while the high-class inmates feel superior and different from the low-class inmates. This study tends to understand the different treatment between the low-class inmates and high-class inmates which hampers reformation, rehabilitation, and re-integration of Inmates back to the larger society and could ultimately cause recidivism (Francis, Johnson and Nagin, 2011, Madaki, 2011, Aborisade, 2019). Also, the difference in status affects Correctional official's enforcement of certain extant rules on High-Profile Inmates owing to their high degree of social capital, and due to that different problems could ensue as a result of the differential treatments amongst the inmates. It is therefore important to understand the different treatments and how such treatments affect the genuine essence of incarceration. 


\subsection{Theoretical Background}

Max Weber's theory of life chances was adopted for this Study. The analysis of social class entails the analysis of how the various groupings or strata interact with each other; often we discovered that they interact together unequally. One group may acquire and be satisfied with more economic resources than another or it might be more respected than another or better still may be of higher status than other groups in that society. In human interactions, there are those have and those have not and there are families of great birth status and family of commoners and there are the political leaders who maybe elites and there are those who are political trivial and political Lilliputian. The latter are followers who are expected to obey commands from the former.

The study of social class concerns itself with the need to understanding how inequalities arise in the society, its continuity or its extinction over a period of time which affects all aspects of social life. Class, status and party have consequences for what Weber (1920) calls "life chances" (opportunity to improve one's life) (labinjo, 2002). These opportunities are unequal and so those who have better opportunities and happen to find themselves in correctional centres may exert some influence on others (Isiugo-Abanihe Isamah and Adesina, 2002).

Life Chances are probabilistic concepts describing how likely it is, given certain factors, that an individual's life will turn out in a certain way. According to this theory life chances are positively correlated with one's socio-economic Status Life-Chances which is a consequence of one's socioeconomic status is therefore, opportunities each individuals has to improve his/her quality of life (White, 2006). Opportunities connote in this case, the extent to which one has access to resources both tangible and intangible such as food, clothing, and shelter while intangible such as education and health care (Cookerham, 1999, Fitzpatrick and Lagory, 2000, Cookerham, 2005). Life chances are either ascribed or achieved (Gugushvil, 2014).

A Correctional Centre is not a classless society. Within the correctional centres, there are class structures, status groups and party affiliations among inmates (Ahmadu, 1985, cap p.29 laws of Nigeria2004, Nigeria Correctional service order (2012). Therefore, in the course of treatment of inmates, there may be special consideration for special class Inmates because the classes of all Inmates will influence their life chances in custody. Thus, the social status class and party affiliations of Inmates may determine the kind of accommodation, bed and beddings, clothing, food, health care services and other treatments that individual Inmates may benefit from the Correctional Centre authority.

\subsection{Objectives of the Study}

The general objective of this study was to investigate the problems emanating from differential treatment of Inmates in
Lagos Correctional Centres. The specific objectives of the study were to:

i. Examine the types of treatment given to High-Profile Inmates.

ii. Investigate the types of treatment given to Low-class inmates.

iii. Investigate the problems arising from differential treatment of Inmates.

\section{METHODOLOGY}

The study adopted a descriptive research design. The study describes the situation within the correctional centre as per the treatment of inmates of different classes as well as the problems arising from differential treatment of Inmates. A survey type of descriptive research was used where both qualitative and quantitative methods of data collection and analysis were used. The research used a multi-stage sampling technique. Lagos Correctional Centre of all categories was purposively selected because they were noted for keeping all Classes of Inmates. Lagos correctional centre sampled includes Kirikiri Correctional Centre (Maximum Security Correctional Centre, and Women Correctional Centre) and Ikoyi Correctional Centre. Taro Yamane formula was used to randomly select 299 general duty Staff and Inmates across the two Correctional Centre selected in KiriKiri and Ikoyi axes to whom questionnaires were distributed. Sixteen (16) Key Informants interviews were also conducted with Staff while 51 in-depth interviews were done which included 42 Inmates and nine trained guards with experience in handling all Classes of Inmates. Of the 299 questionnaires distributed, 256 questionnaires were successfully received. Quantitative data were analyzed using Statistical Package for Social Sciences (SPSS version twenty-three) at univariate and bivariate levels and Qualitative data were analyzed using Nvivo 10 software.

\section{FINDINGS}

Table 1: Respondents' (staff) opinion regarding whether or not special treatment is given to High-Profile Inmates

\begin{tabular}{|c|c|c|}
\hline Respondents' opinion (staff) & Frequency & $\begin{array}{c}\text { Percentag } \\
\mathrm{e}\end{array}$ \\
\hline $\begin{array}{c}\text { There is a special treatment for High-Profile } \\
\text { Inmates in Correctional Centres }\end{array}$ & 215 & 84.0 \\
\hline $\begin{array}{c}\text { There is no special treatment for High-Profile } \\
\text { Inmates in Correctional Centres }\end{array}$ & 41 & 16.0 \\
\hline Total & 256 & 100.0 \\
\hline
\end{tabular}

Source: Field Survey (2021)

\subsection{Types of Treatment given to High-Profile Inmates}

From Figure 1 below, it can be ascertained that $50.0 \%$ of the respondents noted that self-feeding is one of the types of treatment accorded to the High-Profile Inmates. 
Figure 1: Types of treatments given by Correctional Centres authority to High-Profile Inmates

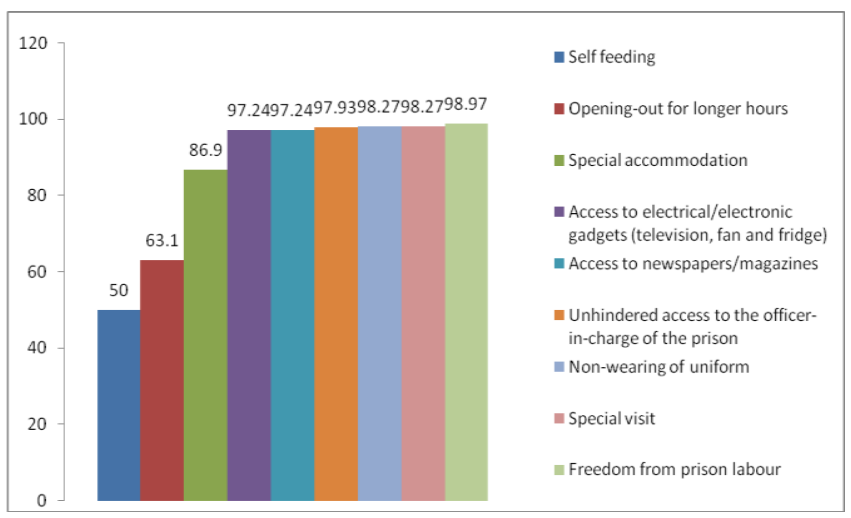

Source: Field Survey (2021)

Self-feeding is allowed in the Correctional Centres on request, through application to the officer-in-charge of the Correctional Centres (Nigerian Correctional Service, SO 237, 2012). Self-feeding is not forbidden for ordinary-class inmates. However, affordability is the issue here. It was discovered that all the 21 High-Profile Inmates interviewed were on self-feeding, while all the 21 ordinary-class inmates interviewed ate Correctional Centres rations. In other words, self-feeding is synonymous with High-Profile Inmates (Akinsuyi, 2016).

It was also discovered that bottled water, and beverages, like Bournvita and Milo were symbolic of HighProfile Inmates' status. However, no Correctional Centres is allowed to receive food outside the food made for the prisoners. No prisoner receiving food at his own expense or that of his friends/family is allowed to share such food with other Correctional Centres (Nigerian Correctional Service 2011, 237 (e).) However, findings during in-depth interview revealed that monitoring of self-feeders was not usually done such that the rules could easily be violated. Also, whoever brings food from outside for a high-profile inmate is usually made to taste such food before handing it over to the inmates. Self-feeding is also tied to Correctional Centres security, in that, sometimes prohibited items, like short saw blades, phones, letters and illicit drugs, have been found to be hidden inside such food items and if Correctional Officials are not vigilant enough, such illegal items could easily be passed on to the inmate, thereby constituting a security threat to the system or health hazard to the inmates concerned. Such illicit items could be recovered during the periodic searching of the inmates and their cells (Adepegba and Folarin, 2016). A respondent gave his opinion about the types of treatment given to High-Profile Inmates:

They are on self-feeding, they have access to magazines and newspapers; they are in special cells that are provided with certain amenities like fans, fridges etc.

(KII, Female, 52 years, Igbo, 5 /2/21)
Furthermore, $63.1 \%$ of the respondents indicated that opening out for longer hours is another treatment that the High-Profile Inmates enjoy. All inmates are entitled to be opened out for bathing and some other activities by 10am daily. They are also opened for the evening activities at $4 \mathrm{pm}$, and all inmates are expected to be finally locked up for night rest between 5:30 pm and $6 \mathrm{pm}$ (Nigerian Correctional Service, 2012). However, High-Profile Inmates often remain outside beyond $6 \mathrm{pm}$ relaxing in the yard even up to $9 \mathrm{pm}$ in some cases, according to our findings; and as such, this is regarded as special treatment. One of the ordinary-class inmates interviewed argued thus:

They are opened out earlier than the ordinary-class inmates. By so doing, they stay outside for longer hours. They do not wear the Correctional Centres uniform and they have access to the officer-in-charge of the Correctional Centres.

(IDI, Male, 33 years, Igbo, Single, 4/2/21)

Also, $86.9 \%$ of the respondents were of the opinion that High-Profile Inmates enjoy being accommodated in noncongested cells. It was found that special blocks of cells which were not congested were a prominent feature of High-Profile Inmates. Any Correctional Centres that houses High-Profile Inmates often reserves a block of cells or at least some cells for High-Profile Inmates' accommodation, which often consists of single bed and neat beddings. Morelle (2014: 21) aptly argues that:

The distribution of inmates initially appears to correspond to three criteria: age, gender and sentence. Thus one notes a minors' wing, a women's wing and another reserved for inmates sentenced to death. But then one notices the presence of several other buildings. In Correctional Centres language, these are known as 'VIP' wings because they are reserved for former members of government and managing directors of semipublic companies prosecuted by the state for misappropriation of public funds in the context of a recent major anticorruption operation. These inmates rarely move through the Correctional Centres grounds without bodyguards, whom they recruit from among their fellow inmates and pay out of their own pockets.

Furthermore, $97.2 \%$ of the respondents also reported access to personal electronic/electrical gadgets to be another form of special treatment. Ordinary-class inmates will not be allowed to bring in electronic gadgets even if they could afford them. Also, the nature of the accommodation of the ordinary-class inmates may not be okay for them to accommodate electronic gadgets for want of space. This is because there would be tight competition for space between human beings and such gadgets. In other words, apart from the fact that the High-Profile Inmates can afford electronic gadgets, and they are so approved, their spacious rooms are conducive to such gadgets. A respondent opined that: 
They have access to electrical and electronic gadgets such as fan, radio and fridge. They also have access to sporting facilities, accommodation is better, their bed and beddings are neat due to self-provision and they drink bottled water.

(KII, Correctional Centres keeper, Male, 44 years, Yoruba, Married, 5/2/21).

The above indicates that High-Profile Inmates who, most of the time, are wealthy individuals enjoy the good things of life in Correctional Centres contrary to the condition experienced by ordinary-class inmates. The opinion of Taibbi (2013) further supports these findings: "Even in the US, wealthy inmates can pay a hundred dollars a day to stay in the upscale city jail in Seal beach, Calif., where they have access to computers and flat-screen televisions."

Also, $97.2 \%$ of the respondents opined that access to newspapers/magazines granted to High-Profile Inmates is another type of treatment. The welfare department is vested with the authority and is duty bound to censor such newspapers and magazines in order to ensure that sensitive news that should not be read by the inmates are removed from such newspapers and magazines. This was supported by a respondent in a key informant interview:

High-Profile Inmates have access to books, newspapers and magazines. They are on self-feeding and they have free movement within the Correctional Centres yard.

(KII, Female, 42 years, Igbo, 28/2/21)

Another treatment accorded to High-Profile Inmates, according to $97.9 \%$ of the respondents, is unhindered access to the officer-in-charge of the Correctional Centres as well as other senior officials. It is considered a big privilege interacting with High-Profile Inmates which could be beneficial to the officials concerned. Also, the findings revealed that most High-Profile Inmates enjoyed interacting with the officer-in-charge of the station, as well as other senior officials, including the Correctional Centres keeper, as a status-symbol.

As soon as some High-Profile Inmates are opened out, after taking their bath and breakfast, they usually proceed to the offices, sit down with officers and begin to interact with them. The officials involved see the interactions with HighProfile Inmates who are probably ex-state governors, ministers, big businessmen and the like as a huge privilege and social capital. On the part of the High-Profile Inmates, they feel honoured and derive satisfaction from such interactions, which help to lessen the pains of inmates in Correctional Centres. Besides, High-Profile Inmates know that such a privilege is hard for ordinary-class inmates to come by. This assertion was buttressed by a retiree in a key informant interview, when questioned on whether, from his experience, Correctional Officials sometimes find it difficult to enforce the rules and regulations on High-Profile Inmates:
High-Profile Inmates are difficult to control; in fact, they behave like officers in the Correctional Centres. As soon as they are opened out, they move to the offices, sit down with their officer friends and some of them don't go back to their cells until the officers close for the day's work.

\section{(KII, Retiree, 61 years, 10/3/21)}

Special visit to High-Profile Inmates was also viewed as one of the treatments by $98.3 \%$ of the respondents. Special visits are visits outside the provision of the Correctional Standing Order (2011) Section 160 and 164 which provides that:

160(a) visits to convicted inmates shall take place between 0900 hours to 1400 hours on Saturdays and Sundays and at such other times as the Superintendent-incharge of Correctional Centres may allow. Visits by a lawyer but not a lawyer's clerk, shall be under similar conditions except that the officer conducting the visit shall be able to see but not hear what is taking place.

(b) In every case the visit to a condemned inmate whether by a lawyer or any other visitor shall be in the sight and hearing of at least two Correctional Centres staff.

(c) Visits to un-convicted inmates shall take place between 0900 hours to 1400 hours on Mondays to Fridays and at such other times as the Superintendent-incharge may allow.

164. No inmate shall be allowed more than three visitors at one time. Substituting one visitor for another shall be permitted only once.

The Special visit comes in different forms. It could be visit outside the official day and time specified for different categories of inmates. It could be in the form of staying beyond allotted time of visit, which is 30 minutes. It could also be in the form of allowing more than maximum number of visitors at a time, which is three persons per inmate. Even in the United States, special visit is also part of the Correctional Centres system, as averred by Writers (2011):

In July 2010, Hollywood bad girl Lindsay Lohan was sentenced to 90 days in jail for violating her terms of probation. Lohan was also ordered to check into an inpatient rehab program after her release from jail. Not only did Lohan get off easy with a short 14 day stay because of Correctional Centres overcrowding, but she also received preferential treatment behind bars. She continued to receive her usual prescriptions medications in jail and got to have visitors even after official visiting hours. Lohan was also allowed to order food from a special store and could have specific items delivered to the jail that weren't readily available.

The fact that Lohan continued to have visits after visiting hours, as indicated above, connotes a special visit she enjoyed in Correctional Centres as a high-profile inmate. 
In addition, $98.3 \%$ of the respondents identified nonwearing of inmates' uniform as one of the treatments. Awaiting-trial inmates (non-convicts) are expected to wear green uniform, while the convicted inmates wear blue uniform. However, High-Profile Inmates wear mufti, including trousers and some other fashionable dresses, like track suits. This privilege of non-wearing of uniform given out to High-Profile Inmates could make them psychologically alright, giving them a relief out of the so many pains of inmates within Correctional Centres (Alabi and Alabi, 2011). This position was buttressed in an FGD session thus:

High-Profile Inmates enjoy the privileges of not wearing uniform, special cells, special feeding and free movement.

(FGD, 27/3/21)

Finally, $99.0 \%$ of the respondents identified nonengagement of the High-Profile Inmates in Correctional Centres labour as one of the treatments. High-Profile Inmates, by the nature of their profession and career prior to incarceration, are not used to Correctional Centres labour. They are people who engaged in white-collar jobs prior incarceration and, therefore, Correctional Centres labour could easily put their health at risk, unlike ordinary-class inmates. Leblond (2015), an American and Canadian exconvict, talking about his experience on what Correctional Centres is like for rich and famous people, argued that very rich people find someone who will work for them in Correctional Centres instead of engaging in Correctional Centres labour. This situation is similar in Nigerian Correctional Centres. Rich people engage ordinary-class inmates as house helps. In a key informant interview, a respondent argued thus:

High-Profile Inmates don't engage in Correctional Centres labour; they are given special accommodation and they are allowed to feed themselves.

(KII, Male, 50 years, Hausa, 24/2/21)

However, High-Profile Inmates who are political detainees could be denied access to the aforementioned privileges in respect of visits, newspapers, and even decent accommodation, among others, due to political reasons (Soyinka, 1972).

\subsection{Types of treatment given to Low-Class Inmates}

Table 2 below shows that $22.8 \%$ of the respondents noted that the ordinary-class inmates are not allowed to have special visits. Special visits are visits outside the provision of the Correctional Standing Order (2011) Section 160 and 164 quoted earlier (see page 8 of this work).
Table 2: Types of treatments given to Low-Class Inmates

\begin{tabular}{|c|c|c|}
\hline Dimensions Aspect? & Frequency & Percentage \\
\hline Have no special visit & 66 & 22.76 \\
\hline Accommodated in overcrowded cells & 92 & 31.72 \\
\hline $\begin{array}{c}\text { General feeding (depending mainly on } \\
\text { Correctional Centres food) }\end{array}$ & 108 & 37.24 \\
\hline Locked up at the normal time & 113 & 38.97 \\
\hline Opened out for lesser hours & 166 & 57.24 \\
\hline Made to wear Correctional Centres uniform & 185 & 63.79 \\
\hline Engage in Correctional Centres labour & 189 & 65.17 \\
\hline
\end{tabular}

Source: Field Survey (2021)

Poor offenders hardly even receive visits in Correctional Centres. Special visits is almost insignificant for ordinary-class inmates, unlike wealthy politicians and businessmen who are in Correctional Centres and are daily and frequently visited by friends, relations, business partners or associates who want to derive one benefit or the other from such wealthy inmates. Most of the time, poor and lowly inmates in the Correctional Centres are often forgotten by their relations, friends and associates. The reasons for this include inability of such friends, relations and associates to afford financial and material resources required to visit such inmates in Correctional Centres. Also, unlike the visitors of the High-Profile Inmates, such visitors know that they probably would not derive any benefit from poor inmates who could hardly afford to hire the services of lawyers to secure their freedom even when they have good cases.

Also, $31.7 \%$ of these respondents reported that the ordinary-class inmates are accommodated in overcrowded cells. This is because the overcrowded dormitory is meant for the masses that are of low status who cannot "buy" their ways to the special accommodation meant for the High-Profile Inmates. Overcrowded cells have a lot of negative implications for the much desired objective of the Correctional Centres, which is reformation, rehabilitation and reintegration of offenders back to the society. Overcrowded cells presuppose that the entire Correctional Centres itself must have been congested, that is, such a Correctional Centre must be locking more than its designed capacity. According to Akpe (2016:53):

A Correctional Centres is adjudged congested when the inmates who are incarcerated there exceed the number which was initially allocated to it. The Correctional Centres lock-up figure is arrived at by dividing the living space by three square meters per inmate. An inmate, according to the United Nations Standard Minimum Rules for treatment of Inmates, is entitled to a space of 3 meters by 3 meters.

Overcrowded cells make classification of inmates difficult. They certainly lead to poor ventilation, can easily breed skin diseases and other diseases, and can easily cause fighting/rioting as a result of unhealthy competition for 
sleeping spaces and for use of the cell conveniences, such as toilets and bathrooms. Therefore, overcrowded cells generally make the administration of inmates difficult. The above corroborates the opinion of Ogadimma, Adejumo and Asamu (2015), who assert that:

Correctional Centres houses are not too different from other human communities that often face some life posing challenges. In most circumstances, Correctional Centres crises were staged to point out some lapses on the part of government to making life bearable to Correctional Centres inmates. Among these lapses may include; overcrowding, lack of medical facilities and personnel, poor quality and quantity of food, poor ventilation, poor sanitation and incessant death among inmates.

The above claim also supports the opinion of Otero (2012) and Morelle (2014) on the poor conditions of Correctional Centres and inmates in Africa generally.

A total of $37.2 \%$ of the respondents were of the opinion that the ordinary-class inmates depend only on the food provided by the authority. As earlier mentioned, selffeeding is not restricted to High-Profile Inmates only. But ordinary-class inmates do not enjoy self-feeding because they are too poor to afford it. Also, relations of ordinary-class inmates are too poor to afford the rigorous requirements of bringing food and water for such inmates on a daily basis. In most cases, how to secure legal services in order that such inmates could regain their freedom will be their priority. An ordinary-class inmate gave his opinion regarding the types of treatment they receive:

We eat the general inmates' food that is given to us by the Correctional Centres authority, we are taken out to cut grass in and outside the Correctional Centres, and we also do the cleaning of drainages.

\section{(IDI, Female, 30 years, Urhobo, Single, 6/3/21)}

Furthermore, $39.0 \%$ of the respondents indicated that the ordinary-class inmates are locked within the normal (approved) lock-up time. This means that they are not allowed to stay outside after the mid-day lock-up at 1:30 pm until 4 $\mathrm{pm}$, when they are opened out for sports or evening activities and are not also allowed to remain outside after the final lockup at $6 \mathrm{pm}$. This is because, averagely, officials do not have confidence in this category of inmates because of their low socio-economic status. The tendency to misbehave is considered higher in them than in the High-Profile Inmates.

In addition, $57.2 \%$ of the respondents were of the opinion that the ordinary-class inmates are opened out for lesser hours. These lesser hours of opening-out, as reported here, is in comparison with the kind of unfettered freedom being enjoyed by the High-Profile Inmates. Opening out for lesser hours being referred to here is in conformity with the Correctional Standing Order 2011 (Nigerian Correctional Service, 2011, SO 537). However, unlike the High-Profile Inmates who use their opening-out hours to engage in discretionary activities, including going to the offices, the ordinary-class inmates are expected to get themselves engaged in workshop activities, learning one trade or the other, cooking in the kitchen and fetching water among others. With this, it could be deduced that the ordinary-class inmates are the ones that are really involved in the Correctional Centres program of reformation, rehabilitation and reintegration. A respondent in a key informant interview opined thus:

They are opened out only on official hours, they depend mostly on normal ration (Correctional Centres food) and they are used for labour gangs. (KII, Male, 52 years, Igbo, 23/2/21)

The responses from $63.8 \%$ of the respondents showed that ordinary-class inmates wear inmate's uniform. This, in conformity with the law, is the non-wearing of uniform by the High-Profile Inmates that amounts to a violation of the law. Wearing of the Correctional Centres uniform could be considered as an advantage for the ordinaryclass inmates because even if they were given the approval to wear their own clothes, probably only few of them could afford such a venture. This wearing of uniform was supported by an ordinary-class inmate in an in-depth interview:

We always wear the Correctional Centres uniform, we don't have showers in our cells. So we have to go and fetch water outside our cells and we are locked up earlier than the High-Profile Inmates. (IDI, Male, 33 years, Igbo, Single, $4 / 2 / 21$ )

Lastly, $65.2 \%$ of the respondents opined that this set of inmates are used for Correctional Centres labour. Everybody convicted and sent to Correctional Centres is actually meant to serve the Correctional Centresment with hard labour (IHL) (Nigerian Correctional Service, 2011). The exemption granted to the High-Profile Inmates is a mere privilege. This Correctional Centres labour entails, among others, office cleaning, fetching water and breaking of firewood. Office cleaning, fetching water, washing gutters and fetching firewood are considered as menial jobs. Therefore, the probability is high that, given the choice of whom to use for menial jobs between the ordinary-class inmates and the High-Profile Inmates, the ordinary-class inmates would be chosen. This is because it is most improbable that, given the high socio-economic and probably political status of the HighProfile Inmates, that such inmates would be used for menial jobs. The above supports the opinion of a respondent in a focus group discussion regarding the types of treatment given to ordinary-class inmates:

They work in the kitchen. Some are used for gang and other menial jobs. They are accommodated in general cells and they are not allowed to use electronics.

(FGD, 8/3/21)

Atoki (2012:2) summarised the conditions of ordinary-class inmates and Correctional Centres generally in Africa thus: 
Unacceptable levels of overcrowding, disease, physical and psychological abuse by officials and inmates alike, violence, malnutrition, poor hygienic conditions, old dilapidated facilities, harsh disciplinary measures, inadequate medical care for inmates and high mortality rates among inmates are very prevalent in most Correctional Centres on the continent.

Eitzen and Zinn (2003), asserts that many scholars view the entire criminal justice system as unjust. According to them, there is also the degrading and dehumanizing experience of overcrowding and unsanitary conditions which are common in the United States Correctional Centres and more so in Nigeria. The knowledge of the unjust system directed at certain categories of people breeds bitterness and anger regarding African Correctional Centres. Jefferson and Martin (2014:2) observe thus:

We know -- from critical human rights reports, for example - that they are not humane, they are not spacious enough, they do not provide adequate food or health care that they are not just, that inmates are not adequately classified and so on. We know that they do not often live up to externally derived standards and norms.

However, regardless of the poor condition of Correctional Centres, especially, as regards the circumstances and the situation of the ordinary-class inmates, they would find means of survival. As aptly argued by Soyinka (1972:9):

But no matter how cunning an inmate, no matter how ingenious - and the definition of an inmate's nature is animal cunning - the humanitarian act of courage by the exception among his gaolers plays a key role in his survival.

\section{SUMMARY}

This research work was aimed at investigating discriminatory treatment of Inmates in Nigerian prisons. The presence of High-Profile Inmates who are of a high socioeconomic status, posed some serious challenges to the entire prison system. These challenges could range from demand for better treatment compared to ordinary-class inmates in terms of accommodation, bed and bedding, quality food and water to medical and recreational facilities.

They also constitute a security threat to the entire prison system. Besides, their illegal requests and complaints are challenges. In order to carry out this investigation, three prisons in Lagos Command that are known for keeping HighProfile Inmates were used for this study. They are Maximum Security Prison, Kirikiri, Women Security Prison, Kirikiri, Ikoyi Prison, Ikoyi.

The findings revealed that special treatment was given to these High-Profile Inmates compared to the ordinary-class inmates. This special treatment included self-feeding, access to electrical/electronic gadgets, access to newspapers/magazines, special visits (visits beyond allotted time and at a more conducive place), special (non-congested) accommodation, and so on. This is in contrast to the treatment accorded the ordinary-class inmates. The ordinary-class inmates are accommodated in congested cells, they are malnourished, and they engage in prison labour, among others.

The study also revealed that the consequence of the different treatment meted out to the two classes of inmates breed frustration, anger, feelings of deprivation etcetera among some of the ordinary-class inmates. However, contrary to expectation, some of the ordinary-class inmates did not feel so uncomfortable with their treatment, provided they benefited from free food and clothing among others from the High-Profile Inmates also, they had the opportunities to undergo vocational training as well as further their education. On the other hand, the High-Profile Inmates were happy with the way they were treated.

The study further found that some of the staff of Nigerian Prison Services encountered difficulties in enforcing prison rules and regulations on the High-Profile Inmates. These difficulties, at times, emanated from the inferiority complex of the staff and the tendency of these High-Profile Inmates to look down on staff. Some of these rules and regulations often contravened by High-Profile Inmates relate to illegal use of phones in the prison, disrespect of staff by the inmates, exceeding time allotted for visits, inducement of staff, and exceeding time allotted for open-out.

Moreover, it was discovered that lack of specially trained personnel was a major challenge to the management and staff when dealing with High-Profile Inmates. Other challenges identified were undue influence on staff, security threat/outright escape, health issues, difficulty to adapt to the prison environment by these inmates, inadequate housing and recreational facilities, difficulty in controlling them, rudeness to staff, illegal requests that threaten the security of the prison, and so on.

\section{CONCLUSION}

The Correctional Centre, as an institution, houses different classes of inmates (convicted and un-convicted) with various lengths of incarceration as well as different socioeconomic statuses. Therefore, the ability of the prison management and staff to adequately handle these various classes of inmates, especially the High-Profile and the LowProfile Inmates lies in the hands of the correctional officers. Some of these High-Profile Inmates come into the prison with their inflated egos and prove difficult to deal with. Others are psychologically and emotionally affected. They often find it difficult to adapt and re-socialize within the prison system.

Imprisonment is a punishment in itself. Therefore, in order not to inflict further punishment, especially on this class of inmates, the prison management accord them certain privileges that do not threaten the security of either these 
inmates or the entire prison system. This "special" treatment elicit different feelings and reactions from the High-Profile Inmates and ordinary-class inmates.

Despite this special treatment, the presence of the High-Profile Inmates in prison poses some challenges, such as security threat, outright escape, and inducement of staff, and disrespect to staff. In addition, the staff often found it difficult to enforce the prison rules and regulations on these inmates. Also, the presence of high- Profile Inmates in prison imposes on the management challenges of providing adequate institutional facilities, like accommodation, as well as medical and recreational facilities. The low-class inmates may exhibit the following tendencies towards the system: rudeness to staff or outright revolt or riot, disobedience of rules and regulation, rejection of food and other facilities such as bed and bedding all because they feel alienated by the treatment given to their high-profile colleagues. The above generally make the management of correctional centers very difficult.

\section{REFERENCES}

[1] Aborisade, R., Akanle, O. and Omobowale, A.O. Ed. 2013. Essentials of sociology. Ibadan University.

[2] Aborisade, R.A (2019). Differential treatments of Prison inmates and implications on Nigerian criminal justice system. University of Ibadan. Journal of Sociology, 2019

[3] Adepegba, A. and Folarin, S. 2016. Kuje Correctional Centres Riot: Boko haram inmate caught with 25 phones. www.punch.com.ng/kuje-Correctional Centres-riot-bharaminmate-caught-with-25-phones. Retrieved 28/1/17

[4] Ahmadu, A. A.1985.Nigerian Correctional Service: staff duties manual. Abuja, Federal Ministry of Internal Affairs.

[5] Akinsuyi, Y. 2016. Not all inmates can apply for self-feeding, says Correctional Centres boss. www.thisdaylive.com Retrieved $14 / 01 / 17$

[6] Akpe, A. I. 2016. Congestion of Nigerian Correctional Centres: Causes, Challenges and Solution. Ibadan: Spectrum Books Limited.

[7] Alabi, T. and Alabi, S. O. 2011. Journal of Research in Peace Gender and Development ISSN 2251 -0036 Vol 1(8) p. 235-241

[8] Aminu Musa Ahmed, Abd Halim B. Ahmad. Journal of Social and development Sciences (ISSN 221-1152) Vol. 6 No 2, pp 20-29, June 2015Macmillian Publishers.

[9] Atoki, D. 2012. Protecting Vulnerable Groups in Africa through Correctional Centres Visits. Report of the Special Rapportur on Correctional Centres and Conditions of Detention in Africa at the 52nd Ordinary Session of the African Commission on Human and Peoples Right. Yamoussoukro, Cote d'Ivoire. October 22, 2012

[10] Clarke, M. 2010. Celebrity Justice: Correctional Centres Lifestyles of the Rich and Famous, Correctional Centres Legal News.http://www.Correctional

Centreslegalnews.org/news/2010/jul/15/celebrity-justice-

Correctional Centres-lifestyles- of-the-rich-and-famous/ Retrieved on $7 / 7 / 2014$

[11] Cookerham, W. 1999. Health and Social Change in Russia and Eastern Europe. London, England: Routledge.

[12] Cookerham, W. 2005. The black companion to medical sociology. Oxford, England: Blackwell publishing.

[13] Eitzen D. S. and Zinn M. B. 2003. Social Problems 9th Edition, Boston: Pearson Education Inc.

[14] Fidh- Internationl federation for human rights. www.Fidh.org. Thailand Institute of Justice, Women Prisoners and implementation of the Bangkok Rules in Thailand, Nov. 2014 Page 72. Retrieved 10/6/211
[15] Fitzpatrick, K and La Gory, M. 2000. Unhealthy place: the Ecology of Risk in the Urban Landscape. Hove, United Kingdom: Psychology Press.

[16] Frances, T.C, Johnson C.L, Nagin, D.S (2011), Prisons do not reduce recidivism: The high cost of ignoring science. The prison journal 91(3), 485-655)

[17] Glaze L.E., Correctional population in the United State, 2010. Washington, D.C U.S. Department of Justice 2011(google scholers)

[18] Hornby, A. S. 2006. Oxford Advanced learner's dictionary, (New) Special Price 7th Edition, Oxford: Oxford University Press.

[19] Isiugo-Abanihe, U.C., Isamah A.N. and Adesina J. O. Eds. 2002. Quantitative research techniques Currents and perspective in sociology. Lagos: Malthouse Press Limited.

[20] Jefferson, A. M. and Martin T. M. 2014. Correctional Centres service Journal. Everyday Correctional Centres governance in Africa. Page 2

[21] Olorunmola, J.J, 2018. The management of High-Profile Prison Inmate in Lagos Nigeria: a thesis submitted in partial fulfillment of a Degree of Doctor of Philosophy of the Faculty of the Social Sciences, University of Ibadan, Nigeria.

[22] Kristin Turney, Hedwig.Lee and Megan Comfort: American Journal of men's health. www.ncbi.nih.gov. Retrieved thesis

[23] Labinjo, J. 2002. The Sociological trio: an introduction to Marx, Weber and Durkheim. Currents and perspectives in sociology. Isiugo-Abanihe, U.C., Isamah A.N. and Adesina J. O. Eds. Lagos: Malthouse Press Ltd.

[24] Leblond, D. 2015. What is Correctional Centres like for rich and famous people? www.quora.com Retrieved 12/01/17

[25] Madaki, M., (2011) A study of the Legal Right of Convicted Prisoners and the unintended Consequenses of Incarceration in Kano Central and G/Dutse Prisons, Nigeria unpublished Ph.D. Dissertation. Submitted to the Department of Sociology, Bayero University Kano

[26] Malala, J. 2016. High-profile Criminal cases expose inequality in South Africa's justice System. www.theguardian.com Retrieved $12 / 01 / 17$

[27] Morelle, M. 2014. Correctional Centres service Journal. Power, control and money in Correctional Centres: The informal governance of the Yaounde Central Correctional Centres. Page: 21.

[28] Nicola Slawson 2017: www.amp.the guardian. Retrieved $10 / 6 / 2021$

[29] Nigerian Correctional Service 1970, circular 2119170, 18th September, 1970, on treatment of High-Profile Inmates.

[30] Nigerian Correctional Service 2009.Annual report. Abuja, Nigerian Correctional Service, Headquarters, Publication

[31] Nigerian Correctional Service 2004, Cap P.29 Laws of the Federation of Nigeria. Abuja: Federal Government Press.

[32] Nigerian Correctional Service 2011.Standing Orders Revised Edition. Federal Ministry of Justice and Inmates Rehabilitation and Welfare Action. Lagos: Federal Government Printer.

[33] Nigerian Correctional Service 2012.Lecture manual for trainings and promotion examinations for all Correctional Centrestaff. Abuja: Nigerian Correctional Service, Headquarters.

[34] Nigerian Correctional Service 2012. Lecture Manual. Revised Edition. Abuja: Nigerian Correctional Centre Service, Headquarters.

[35] Nigerian Correctional Service 2012. Correctional Centre Staff College Kaduna lecture manual for training and promotion examination for all Correctional Centres staff. Revised Edition. Kaduna: Creative Press.

[36] Ogadimma, C.A. Adejumo, Y. P. and Asamu, F. F. 2015. Causes and effects of violence in Nigerian Correctional Centres; Journal of Social Sciences and Humanities. Page 368. Washington DC, American Institute of Science.

[37] Okunola, R. A., Aderinto, A. A. and Atere, A. A. 2002. The Correctional Centres as asocial system. Currents and perspectives in sociology. Lagos: Malthouse Press Limited.

[38] Otero. M. 2012. A practical guide to understanding and evaluating Correctional Centres system. Bureau of International 
Narcotics and Law Enforcement Affairs, Bureau of Democracy, Human Rights and Labour. Bureau of Consular Affairs. United States Department of States. Washington DC 20520: A/GIS/GPS Printers.

[39] Schaefer, R. T. 2012. Sociology. New York: McGraw-Hill Company.

[40] Schmalleger, F. 1974. Criminal justice today: an introductory text for the $21^{\text {st }}$ century London: Prentice Hall International.

[41] Scott, J. and Marshall, G. 2005. Oxford dictionary of sociology. Oxford: Oxford University Press.

[42] Soyinka, W. 1972. the man died. Correctional Centres notes of Wole Soyinka. London: Rex Collins Limited.
[43] Taibbi, M. 2013. Wealthy criminals pay to stay in fancy Correctional Centres. www.today.com Retrieved 13/1/17

[44] Wakefield S., Uggen C, 2010. Incarceration and stratification Annual review of Sociology; 36(I) 387-406: google scholars

[45] White, K. 2006. 'life-chances' The Cambridge dictionary of Sociology. Ed Bryan S. Turn. Cambridge, United Kingdom: Cambridge University Press.

[46] Writers, S. 2011. 10 most pampered celebrity inmates. www.criminaljusticeusa.com/blog/2001/10-most-pamperedcelebrity-inmates Retrieved 28/1/2017

[47] Yamane, T. 1967. Statistics: an introductory analysis, 2nd Edition. New York: Harper and Row. 